\title{
PEMBUATAN ASAM OKSALAT DARI PELEPAH KELAPA SAWIT MENGGUNAKAN METODE PELEBURAN ALKALI
}

\author{
Seri Maulina, M Hidayat Hasibuan* \\ Departemen Teknik Kimia, Fakultas Teknik, Universitas Sumatera Utara \\ Jl. Almamater Kampus USU Medan, 20155 Indonesia \\ *Email: mhidayathsb91@gmail.com
}

\begin{abstract}
Abstrak
Pelepah kelapa sawit merupakan salah satu limbah padat dari perkebunan kelapa sawit yang mengandung bahan berlignoselulosa yaitu selulosa, hemiselulosa, dan lignin. Selulosa dari limbah pelepah kelapa sawit dapat diolah lebih lanjut menjadi produk yang bermanfaat dan bernilai ekonomis, salah satunya dengan dimanfaatkan sebagai bahan baku pembuatan asam oksalat. Tujuan penelitian ini adalah mengkaji pengaruh temperatur dan waktu reaksi pada hidrolisis pelepah kelapa sawit dengan metode peleburan alkali dalam menghasilkan asam oksalat. Penelitian ini terdiri dari dua tahap, yaitu tahap preparasi pelepah kelapa sawit dan tahap sintesis asam oksalat yang meliputi proses peleburan alkali dan kristalisasi. Analisis yang dilakukan terhadap bahan baku meliputi analisis kadar air dan kadar selulosa pelepah kelapa sawit. Dari hasil penelitian ini diperoleh kadar air sebesar 53,7\% dan kadar selulosa sebesar 30,9\%. Pada penelitian ini analisis kuantitatif yang dilakukan berupa konversi selulosa dan yield asam oksalat. Dari hasil penelitian ini diperoleh kondisi optimum pada temperatur reaksi $90{ }^{\circ} \mathrm{C}$ dan waktu reaksi 60 menit dengan konversi selulosa sebesar 79,2\% dan yield asam oksalat sebesar 59,6\%. Untuk analisis kualitatif meliputi analisis kemurnian menggunakan FTIR dan analisis titik leleh. Hasil analisis FTIR menunjukkan bahwa gugus telah mendekati asam oksalat standar dan titik leleh sebesar $101,8{ }^{\circ} \mathrm{C}$ menunjukkan bahwa asam oksalat yang diperoleh berupa asam oksalat dihidrat.
\end{abstract}

Kata kunci: pelepah kelapa sawit, asam oksalat dihidrat, peleburan alkali

\begin{abstract}
Palm frond is one of the solid waste from oil palm plantations which contains lignocellulose namely cellulose, hemicellulose, and lignin. Cellulose from waste palm fronds can be further processed into useful products and economic value, one of which is used as raw material for making oxalic acid. The purpose of this research is assess the effect of temperature and reaction time in the hydrolysis of palm fronds with alkali fusion method of producing oxalic acid. The research consisted of two stages that is the stage of preparation of palm fronds and the stage of oxalic acid synthesis, which include alkali fusion and crystallization processes. Analysis of the raw materials include the analysis of water content and cellulose content of palm fronds. From the results of this study showed water content is $53.7 \%$ and cellulose content is $30.9 \%$. At this research for quantitative analysis includes the conversion of cellulose and yield oxalic acid. From these results obtained optimum conditions at a reaction temperature of $90{ }^{\circ} \mathrm{C}$ and a reaction time of 60 minutes the cellulosic conversion is $79.2 \%$ and a yield is $59.6 \%$ oxalic acid. For qualitative analysis includes purity analysis using FTIR and melting point analysis. FTIR analysis results indicate that the group has approached the standard of oxalic acid and melting point of $101.8^{\circ} \mathrm{C}$ which indicates that the oxalic acid is obtained in the form of oxalic acid dihydrate.
\end{abstract}

Keywords: palm fronds, oxalic acid dihydrate, alkali fusion

\section{Pendahuluan}

Perkebunan kelapa sawit yang terus berkembang di hampir seluruh provinsi di Indonesia menempatkan Indonesia sebagai penghasil minyak kelapa sawit terbesar di dunia yang diikuti oleh Malaysia sebagai pesaing utama Indonesia [10]. Perkembangan perkebunan kelapa sawit berdampak pada peningkatan limbah dari perkebunan tersebut yang belum dimanfaatkan secara optimal. Limbah yang dihasilkan dari tanaman kelapa sawit mulai dari pra panen hingga proses pemanenan, salah satunya adalah pelepah kelapa sawit. Ditinjau dari komposisi kimianya limbah pelepah kelapa sawit mempunyai potensi yang cukup besar untuk diolah lebih lanjut menjadi produk yang bermanfaat dan bernilai ekonomis, salah satunya dengan memanfaatkan limbah pelepah kelapa sawit sebagai bahan baku pembuatan asam oksalat [1]. 


\section{Teori}

Kelapa sawit (elaeis guineensis) adalah tanaman pohon tropis yang terutama ditanam untuk produksi industri minyak nabati. Habitat asli kelapa sawit adalah hutan hujan tropis dengan curah hujan $1780-2280 \mathrm{~mm}^{3}$ per tahun dengan kisaran suhu 24 $-30{ }^{\circ} \mathrm{C}$. Kelapa sawit juga toleran dengan berbagai jenis tanah asalkan mendapat pasokan air yang cukup [6]. Untuk pertumbuhan dan produksi yang optimal, tanaman kelapa sawit membutuhkan curah hujan yang tinggi dan suhu yang stabil sepanjang tahun, tanah harus dalam dan berdrainase baik. Tanaman kelapa sawit tumbuh terutama di dataran rendah daerah tropis di bawah ketinggian $400 \mathrm{~m}$ [12]. Total potensi jumlah limbah pelepah kelapa sawit di Indonesia sebanyak 81.887.936 ton/tahun [11]. Nutrisi pelepah kelapa sawit meliputi 5,8\% protein kasar, 48,6 \% serat kasar, dan 3,3\% abu [3]. Dari data tersebut dapat diketahui bahwa komponen penyusun terbesar dari pelepah kelapa sawit adalah serat kasar. Serat kasar pelepah kelapa sawit terdiri dari selulosa, hemiselulosa, dan lignin.

Tabel 1. Komposisi Kimia Pelepah Kelapa Sawit [4]

\begin{tabular}{|l|c|}
\hline \multicolumn{1}{|c|}{ Komponen Kimia } & Kadar (\%) \\
\hline Selulosa & $31,5 \pm 0,3$ \\
\hline Hemiselulosa & $19,2 \pm 0,1$ \\
\hline Lignin & $14,0 \pm 0,5$ \\
\hline Abu & $12,3 \pm 0,2$ \\
\hline Protein & $9,4 \pm 0,1$ \\
\hline
\end{tabular}

Selulosa adalah senyawa berbentuk benangbenang serat, terdapat sebagai komponen terbesar dalam dinding sel pepohonan, jerami, rumput, enceng gondok, dan tanaman lainnya. Selulosa pada tanaman merupakan serat-serat panjang yang bersama-sama hemiselulosa membentuk 5 dan 6 karbon gula dan lignin. Molekul-molekul tersebut berikatan dan membentuk rantai panjang dari kesatuan D-glukose yang dihubungkan oleh rantai $\beta$ glukosida1,4.

Asam oksalat disintesis untuk pertama kali pada tahun 1776 oleh Scheele melalui oksidasi gula dengan asam nitrat. Asam oksalat banyak digunakan dalam industri sebagai bahan pembuat seluloid, rayon, bahan peledak, penyamakan kulit, pemurnian gliserol dan pembuatan zat warna. Selain itu asam oksalat juga dapat digunakan sebagai pembersih peralatan dari besi, katalis, dan reagen laboratorium [5]. Asam oksalat dapat dihasilkan dari bahan-bahan berselulosa dengan metode peleburan alkali. Pembuatan asam oksalat dengan proses peleburan alkali dilakukan menggunakan bahan baku yang mengandung selulosa tinggi seperti serbuk gergaji, sekam padi, tongkol jagung, dan lain-lain. Bahan ini dilebur dengan alkali hidroksida seperti natrium hidroksida atau kalsium hidroksida pada suhu $240-285{ }^{\circ} \mathrm{C}$. Produk yang diperoleh direaksikan dengan asam sulfat untuk membentuk asam oksalat dan kalsium sulfat [2]. Berikut reaksi-reaksi yang terjadi pada proses peleburan alkali menggunakan alkali $\mathrm{Ca}(\mathrm{OH})_{2}$ dimana tidak digunakan $\mathrm{CaCl}_{2}$ pada tahap pengendapan, karena senyawa oksalat hasil dari proses peleburan telah diikat oleh ion $\mathrm{Ca}^{2+}$ dari $\mathrm{Ca}(\mathrm{OH})_{2}$ yang berlangsung secara simultan dengan proses peleburan tersebut.

Tahap Peleburan Alkali :

$2\left(\mathrm{C}_{6} \mathrm{H}_{10} \mathrm{O}_{5}\right) \mathrm{n}+3 \mathrm{n} \mathrm{Ca}(\mathrm{OH})_{2}+13 / 2 \mathrm{n} \mathrm{O}_{2} \rightarrow \mathrm{n}$ $\mathrm{CaC}_{2} \mathrm{O}_{4}+\mathrm{nCa}\left(\mathrm{CH}_{3} \mathrm{COO}\right)_{2}+\mathrm{n} \mathrm{Ca}(\mathrm{COOH})_{2}+$ $9 \mathrm{nH}_{2} \mathrm{O}+4 \mathrm{nCO}_{2}$

Tahap Pengasaman :

$\mathrm{CaC}_{2} \mathrm{O}_{4}+\mathrm{H}_{2} \mathrm{SO}_{4} \rightarrow \mathrm{C}_{2} \mathrm{H}_{2} \mathrm{O}_{4}+\mathrm{CaSO}_{4}$

\section{Metodologi Penelitian \\ Bahan dan Peralatan Penelitian}

Bahan-bahan yang digunakan dalam penelitian ini yaitu pelepah kelapa sawit, kalsium hidroksida $\left(\mathrm{Ca}(\mathrm{OH})_{2}\right)$, asam sulfat $\left(\mathrm{H}_{2} \mathrm{SO}_{4}\right)$, etanol $\left(\mathrm{C}_{2} \mathrm{H}_{5} \mathrm{OH}\right)$ dan aquadest $\left(\mathrm{H}_{2} \mathrm{O}\right)$. Peralatan yang digunakan adalah Erlenmeyer, beaker glass, refluks kondensor, oven, ball mill,dan hot plate.

\section{Preparasi Pelepah Kelapa Sawit}

Pelepah kelapa sawit dipotong kecil-kecil kemudian dikeringkan di oven dengan temperatur $105{ }^{\circ} \mathrm{C}$ selama 30 menit. Selanjutnya dimasukkan kedalam desikator selama 10 menit dan ditimbang. Dilakukan pengeringan sampai berat pelepah kelapa sawit konstan. Pelepah kelapa sawit yang telah kering dihaluskan menggunakan ball mill dan diayak dengan ayakan 50 mesh.

\section{Sintesis Asam Oksalat}

Pelepah kelapa sawit kering sebanyak 15 gram yang telah diayak dengan ayakan 50 mesh dimasukkan ke dalam labu beaker glass dan ditambahkan dengan $250 \mathrm{ml}$ larutan $\mathrm{Ca}(\mathrm{OH}) 23,5 \mathrm{~N}$. Lalu dipanaskan di atas hot plate pada $\mathrm{T}(70,80,90,100,110){ }^{\circ} \mathrm{C}$ selama t $(40,50,60,70,80)$ menit dengan kecepatan pengadukan $225 \mathrm{rpm}$. Bahan didinginkan selama 10 menit, lalu disaring dan dicuci dengan aquadest panas $\pm 150 \mathrm{ml}$. Filtrat ditambahkan dengan $\mathrm{H}_{2} \mathrm{SO}_{4} 4 \mathrm{~N}$ sebanyak 100 
$\mathrm{ml}$, dan didiamkan hingga terbentuk endapan kalsium sulfat. Kemudian campuran disaring dan dicuci menggunakan etanol $96 \%$ hingga didapat filtrat berupa larutan asam oksalat. Filtrat dipanaskan dengan waterbath pada suhu $70{ }^{\circ} \mathrm{C}$ selama 1 jam. Filtrat didinginkan selama 24 jam sampai terbentuk endapan asam oksalat yang berupa kristal jarum berwarna putih. Hasil yang diperoleh dimurnikan dengan proses rekristalisasi menggunakan pelarut etanol $96 \%$.

\section{Analisis Bahan Baku dan Asam Oksalat}

Analisis bahan baku pelepah kelapa sawit berupa analisis kadar air dengan metode oven dan analisis kadar selulosa dengan metode Chesson Datta. Untuk analisis asam oksalat meliputi analisis kuantitatif berupa yield dan analisis kualitatif berupa FTIR dan titik leleh.

\section{Hasil}

\section{Analisis Kadar Air dan Kadar Selulosa Pelepah Kelapa Sawit}

Bahan baku pelepah kelapa sawit yang digunakan dalam penelitian ini mengandung kadar air sebesar 53,7 \%. Pelepah kelapa sawit yang digunakan dalam penelitian ini diambil pada kondisi cuaca cukup panas sehingga kadar air tidak terlalu tinggi. Sedangkan hasil analisis kadar selulosa pelepah kelapa sawit mengandung selulosa sebesar 30,9 \%. Semakin tinggi kadar selulosa maka yield asam oksalat yang dihasilkan akan semakin besar [7].

\section{Analisis Konversi Selulosa Pelepah Kelapa Sawit}

Konversi selulosa bertujuan untuk mengetahui banyaknya selulosa yang terkonversi menjadi kristal asam oksalat. Berikut Persamaan 1 cara penentuan konversi selulosa.

$$
X=\frac{S_{1}-S_{2}}{S_{1}} \times 100 \%
$$

Dimana:

$\mathrm{X}$ : Konversi selulosa

$\mathrm{S}_{1}$ : Kadar selulosa pada bahan baku

$\mathrm{S}_{2} \quad$ : Kadar selulosa pada residu yang sudah direaksikan dengan $\mathrm{Ca}(\mathrm{OH})_{2}$ pada temperatur dan waktu reaksi yang telah direaksikan

Gambar 1 menunjukkan kurva fluktuasi konversi selulosa terhadap pengaruh temperatur dan waktu reaksi menunjukkan profil konversi selulosa secara umum yang berfluktuasi seiring dengan naiknya temperatur dan waktu reaksi. Konversi selulosa paling optimum diperoleh pada temperatur reaksi $90{ }^{\circ} \mathrm{C}$ dengan waktu reaksi 60 menit. Hal ini kemungkinan disebabkan energi yang diberikan kepada reaktan untuk saling bereaksi lebih besar sehingga lebih cepat selulosa terkonversi menjadi asam oksalat. Tetapi setelah waktu reaksi 60 menit konversi selulosa mengalami penurunan. Konversi selulosa pelepah kelapa sawit yang dihasilkan disajikan dalam gambar 1 .

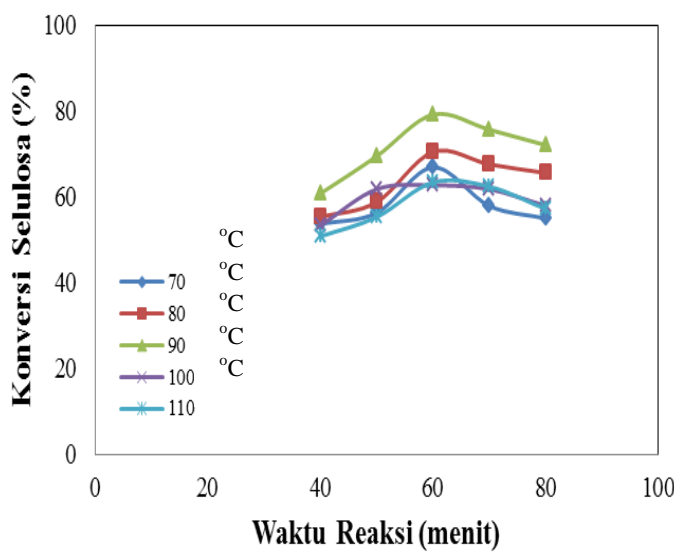

Gambar 1. Pengaruh Temperatur dan Waktu Reaksi terhadap Konversi Selulosa Pelepah Kelapa Sawit

Penurunan konversi selulosa terjadi disebabkan selulosa yang bereaksi dengan $\mathrm{Ca}(\mathrm{OH})_{2}$ yang berupa basa kuat menghasilkan asam oksalat. Kemudian terjadi reaksi lanjut dari asam oksalat berupa reaksi penguraian asam oksalat yang dikenal dengan istilah dekarboksilasi asam oksalat. Reaksi ini menguraikan asam oksalat yang terbentuk menjadi asam formiat, $\mathrm{CO}_{2}, \mathrm{CO}$ dan air [7]. Berikut reaksi dekomposisi asam oksalat:

$2 \mathrm{C}_{2} \mathrm{H}_{2} \mathrm{O}_{4} \rightarrow \mathrm{CH}_{2} \mathrm{O}_{2}+2 \mathrm{CO}_{2} \uparrow+\mathrm{CO} \uparrow+\mathrm{H}_{2} \mathrm{O}$.. (3)

Analisis Yield Asam Oksalat

Yield asam oksalat didefinisikan sebagai:

$$
\text { Yield }=\frac{\mathrm{W}_{\text {asam oksalat }}}{\mathrm{W}_{\text {pelepah kelapa sawit }}} \times 100 \%
$$

Dimana:

$\mathrm{W}_{\text {asam oksalat } \quad \text { : Berat asam oksalat hasil }}$ sintesis

$\mathrm{W}_{\text {pelepah kelapa sawit }}$ : Berat pelepah kelapa sawit

Gambar 2 menunjukkan pengaruh temperatur dan waktu reaksi terhadap yield asam oksalat yang dihasilkan. Secara umum terjadi kenaikan dan penurunan yield dengan naiknya temperatur dan waktu reaksi. Terdapat juga titik optimum pada setiap temperatur reaksi dan waktu reaksinya. Titik optimum 
pada analisis yield asam oksalat yakni pada temperatur $90{ }^{\circ} \mathrm{C}$ dengan waktu reaksi 60 menit. Peningkatan yield disebabkan karena terjadinya fenomena peningkatan energi kinetik pada molekul-molekul reaktan seiring dengan adanya kenaikan temperatur dan waktu reaksi sampai pada titik optimum 60 menit. Hasil analisis yield asam oksalat disajikan pada gambar 2 .

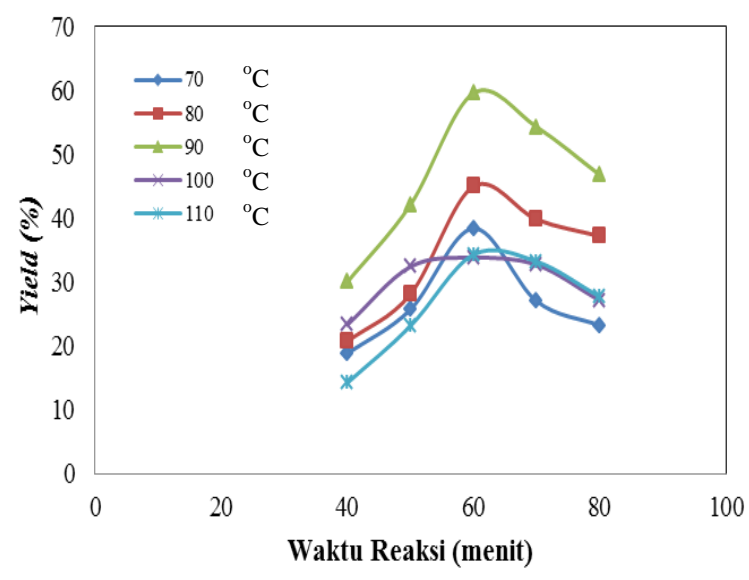

Gambar 2. Pengaruh Temperatur dan Waktu Reaksi terhadap Yield Asam Oksalat

Dengan semakin meningkatnya energi kinetik pada molekul-molekul reaktan, maka semakin besar pula terjadinya tumbukan antar molekul reaktan, sehingga mengakibatkan laju reaksi pembentukan produk juga semakin besar. Kemudian setelah melewati titik optimum pada waktu reaksi 60 menit terjadi penurunan yield yang signifikan. Hal ini kemungkinan juga disebabkan terjadinya reaksi penguraian atau dekarboksilasi asam oksalat. Reaksi ini menguraikan asam oksalat yang terbentuk menjadi asam formiat, $\mathrm{CO}_{2}, \mathrm{CO}$, dan air [7].

\section{Hubungan antara Yield Vs Konversi Selulosa}

Hubungan antara konversi selulosa dengan yield asam oksalat yang dihasilkan yaitu persentase konversi selulosa yang menjadi asam oksalat. Gambar 3 menunjukkan bahwa jika konversi selulosa semakin tinggi maka yield yang dihasilkan juga semakin tinggi. Tetapi pada hasil penelitian ini konversi selulosa tidak secara keseluruhan menghasilkan asam oksalat sehingga yield yang diperoleh menurun setelah konversi selulosa mencapai titik optimum pada temperatur $90{ }^{\circ} \mathrm{C}$ dan waktu reaksi 60 menit. Persamaan reaksi 3 merupakan penyebab konversi selulosa mengalami penurunan sehingga selulosa yang disintesis untuk menghasilkan asam oksalat terurai oleh reaksi lanjut yang dikenal dengan istilah reaksi dekarboksilasi asam oksalat sehingga hasil konversi selulosa menjadi asam oksalat terhambat dan tidak sesuai dengan grafik diatas dimana semakin tinggi konversi selulosa maka semakin tinggi pula yield yang dihasilkan.

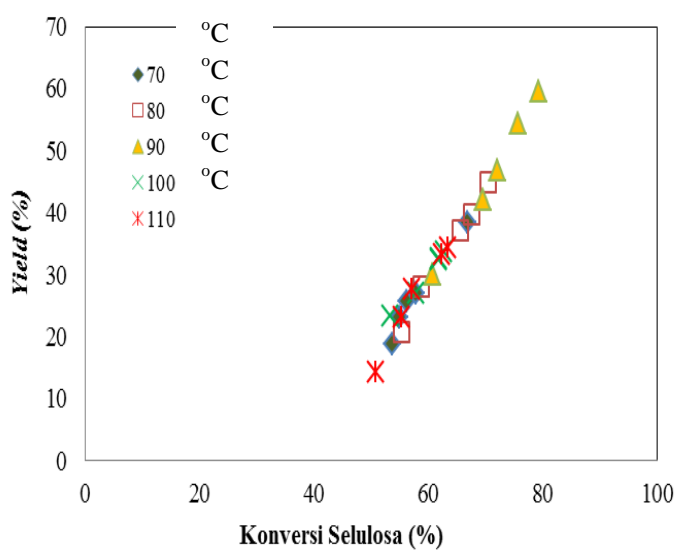

Gambar 3. Konversi Selulosa vs Yield

\section{Analisis FTIR}

Dapat dilihat perbandingan karakteristik antara asam oksalat standar dengan asam oksalat hasil sintesis pada gambar 4 dan 5 .

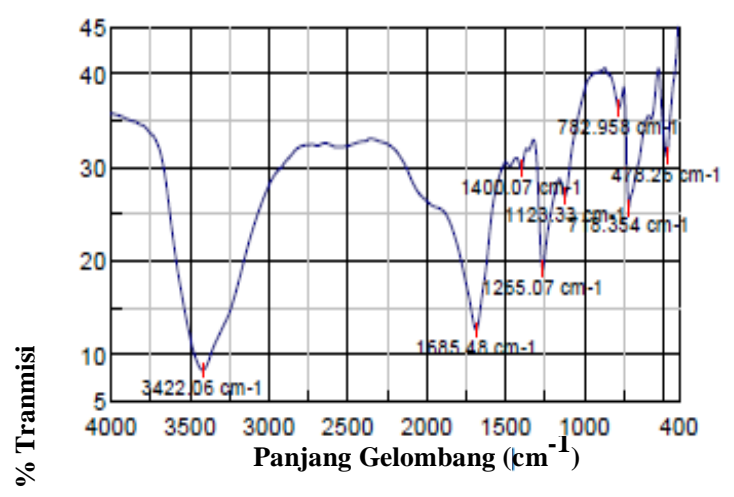

Gambar 4. Spektrum Infra Merah Asam Oksalat Standar [6]

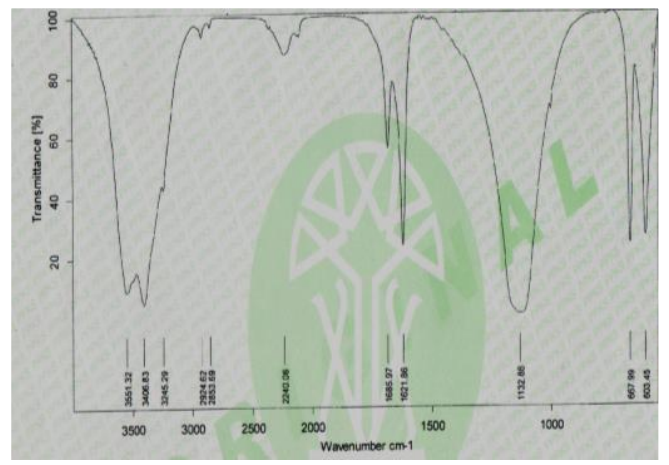

Gambar 5. Spektrum FTIR Asam Oksalat Hasil Sintesis 
Tabel 2. Perbandingan Setiap Gugus Antara Asam Oksalat Standar Dengan Asam Oksalat Hasil Sintesis.

\begin{tabular}{|c|c|c|}
\hline $\begin{array}{c}\text { Gugus } \\
\text { Fungsional }\end{array}$ & $\begin{array}{c}\text { Asam Oksalat } \\
\text { Standar }\end{array}$ & $\begin{array}{c}\text { Asam Oksalat } \\
\text { Sintesis }\end{array}$ \\
\hline $\mathrm{O}-\mathrm{H}$ & 3422,06 & 3406,83 \\
\hline $\mathrm{C}=\mathrm{O}$ & 1685,48 & 1685,97 \\
\hline $\mathrm{C}-\mathrm{O}$ & 1123,33 & 1132,86 \\
\hline $\mathrm{C}-\mathrm{H}$ & 718,35 & 667,99 \\
\hline
\end{tabular}

Vibrasi regangan antara asam oksalat standar dengan asam oksalat hasil sintesis pelepah kelapa sawit memiliki puncak yang tidak jauh berbeda seperti yang terlihat pada Tabel 2. Hal ini membuktikan bahwa dalam penelitian ini, senyawa yang dihasilkan merupakan asam oksalat. Puncakpuncak lain yang terdapat pada hasil analisis FTIR asam oksalat sintesis menunjukkan bahwa asam oksalat yang diperoleh masih belum murni karena masih adanya pengotor pada kristal asam oksalat.

\section{Analisis Titik Leleh}

Analisis titik leleh dilakukan untuk menentukan kemurnian dan juga untuk mengidentifikasi suatu bahan padat [8]. Kristal asam oksalat yang dihasilkan memiliki titik leleh sebesar $101,8{ }^{\circ} \mathrm{C}$. Asam oksalat murni memiliki titik leleh sebesar $101,5^{\circ} \mathrm{C}$ [9]. Dari hasil analisis tersebut asam oksalat hasil sintesis memiliki karakteristik yang sama dengan asam oksalat dihidrat $\left(\mathrm{C}_{2} \mathrm{H}_{2} \mathrm{O}_{4} .2 \mathrm{H}_{2} \mathrm{O}\right)$, maka dapat disimpulkan bahwa produk yang dihasilkan dari penelitian ini merupakan asam oksalat dihidrat.

\section{Kesimpulan}

1. Yield asam oksalat dan konversi selulosa pada penelitian ini memiliki titik optimum pada temperatur $90{ }^{\circ} \mathrm{C}$ dan waktu reaksi 60 menit dengan yield sebesar 59,6\% dan konversi selulosa sebesar 79,2\%.

2. Analisis fisik yang dilakukan terhadap kristal asam oksalat meliputi analisis kemurnian menggunakan FTIR dan titik leleh. Hasil analisis titik leleh yang diperoleh yakni 101,8 ${ }^{\circ} \mathrm{C}$. Hasil ini menyatakan bahwa kristal asam oksalat yang didapat berupa kristal asam oksalat dihidrat.

\section{Daftar Pustaka}

[1] Darni Subari, Utilization of Oil Palm Midrib Waste for Particleboard with an Adhesive Mixture of Phenol Formaldehyde and Acacia Tannin, IOSR Journal of Environmental Science, Toxicology and Food Technology (IOSR-JESTFT), Volume 8 Januari 2014.
[2] Iriany, Andrew Faguh S, Rahmad Dennie A Pohan, Pembuatan Asam Oksalat Dari Alang-Alang (Imperata Cylindrica) Dengan Metode Peleburan Alkali, Skripsi, Universitas Sumatera Utara, Medan, 2015.

[3] Jenny Elisabeth dan Simon P. Ginting, Pemanfaatan Hasil Samping Industri Kelapa Sawit Sebagai Bahan Pakan Ternak Sapi Potong, Skripsi, Medan : Pusat Penelitian Kelapa Sawit, 2003.

[4] Lim Sheh Hong, Darah Ibrahim, Ibrahim Che Omar, Oil Palm Frond for The Production of Bioethanol, International Journal of Biochemistry and Biotechnology, 1 Maret 2012.

[5] Retno Dewati, Kinetika Reaksi Pembuatan Asam Oksalat dari Sabut Siwalan dengan Oksidator $\mathrm{H}_{2} \mathrm{O}_{2}$, Jurnal Penelitian Ilmu Teknik, Vol. 10, No.1 Juni 2010.

[6] Sheila Douglas, Anne Casson, The Impacts and Opportunities of Oil Palm in Southeast Asia, International Forestry Research, Indonesia, 2009.

[7] Seri Maulina, Iloan Pandang, Yos Pawer Ambarita, Comparative Study Of Utilization Of Oil Palm Frond to Produce Oxalic Acid by Using Alkali Fusion and Oxidation Method, Prosiding ICCS, 2015.

[8] Stew Dent, Purity and Identification of Solids Using Melting Points, Department of Chemistry Portland State University Portland, 2006.

[9] SJC Compliance Education, Inc, Safety Data Sheet : Oxalic Acid Dihydrate, 2015.

[10] Tuti Ermawati, Kinerja Ekspor Minyak Kelapa Sawit Indonesia, Pusat Penelitian Ekonomi LIPI, Jakarta, 2013.

[11] Widiatmini Sih Winanti ,Pengembangan dan Alih Teknologi untuk Mitigasi dan Adaptasi Perubahan Iklim, Dewan Nasional Perubahan Iklim, 2014.

[12] Willy Verheye, Growth and Production of Oil Palm, Soils, Plant Growth and Crop Production, Vol 2, Encyclopedia of Life Support Systems (EOLLS), 2011. 